\title{
The Reef Corridor of the Southwestern Gulf of Mexico
}

\author{
Jose de Jesus Salas Perez* \\ Veracruzana University, Mexico
}

*Corresponding author: Jose de Jesus Salas Perez, Veracruzana University, Mexico.

Received Date: December 16, 2018

Published Date: December 19, 2018

\section{Editorial}

The reef corridor of the southwestern Gulf of Mexico, is a coastal area of the state of Veracruz structured by reef ecosystems, are about of 60 known emergent, submerged and marginal reefs from a biological corridor more than $450 \mathrm{~km}$ long, that extend along of that western boundary. The most important reef systems are: The Lobos-Tuxpan Reef System (TLRS) in the northern coastal area, the National Park Veracruz Reef System (NPVRS) in the central coastal area and the Los Turtles Reef System (TRS) in the southern coastal area. These reefs are important due to several oceanographic processes occurred in a broad spectrum of spatial and temporal scales, which arrange from meters to several hundred kilometers and from periods of seconds to years. Moreover those oceanographic processes that take place in the reef corridor of the southwestern Gulf of Mexico, have interactions with several rivers located along the coastal zone, which promotes changes in physicochemical and biological interactions with coral reef ecosystems, which still are not investigated since an multidisciplinary approach, combining studies of physical-biological, physical-geological and physicochemical oceanography of that coastal zone of the western Gulf of Mexico. The NPVRS has been more studied since the point of view of the biological and physical oceanography sciences, because Veracruz port is in the central area of the reef corridor, since several centuries ago, but also because this area was declared a protected natural area in 1992. In contrast, the biology and oceanography of the reef systems of the Northern and Southern areas of the reef corridor, have received little attention. At present results of the physical oceanography, showed that the water mass that irrigate the reef corridor is the Gulf Common Water (GCW) [1,2,3] which sometimes is modified in salinity and temperature by the passage of cold surges during fall to spring. But also, the mixing of the water mass is modified by the diurnal tide which is predominant along the reef corridor, with $\mathrm{F}=3.3[4,5]$. In lesser extent is unknown how the river plumes modify the GCW [6]. The GCW is mainly advected for the wind stress forcing [7], but also could be trapped by sub mesoscale vortex developed by the current with the reefs [8].

The coral connectivity biologically is constricted in two open ocean pathways, the first connecting the Campeche Reef System (CRS) with the Veracruz (VRS) and Tuxpan-Lobos Reef Systems
(TLRS), and the second pathway connecting the Tuxpan-Lobos Reef System with the Flower Garden Reef System (FGRS) [9].

\section{Acknowledgement}

None.

\section{Conflict of Interest}

No conflict of interest.

\section{References}

1. Salas Pérez JJ, Barba GA (2008) Oceanographic characterization of the Veracruz reef system. Atmósfera 21(3): 281-301.

2. Salas Pérez, Virgilio Arenas Fuentes (2011) Water mass of Veracruz reef system. Atmósfera 24: 221-231.

3. Salas Pérez JJ, Jordán Garza AG, Salas Monreal D, González Gandara C (2018) Features and circulation of water masses in the reef corridor of the southwestern Gulf of Mexico.

4. Salas Pérez, JJ, Monreal DS, Fuentes VEA, Salas de León, Riveron Enzastiga (2008) Tidal characteristics in a coral reef system from the western Gulf of Mexico. Ciencias Marinas 34(4): 467-478.

5. Salas Pérez JJ, Jordán Garza AG, Salas Monreal D, González Gandara C (2018) Tides in the reef corridor of the southwestern Gulf of Mexico. In: Oceanography of the reef corridor of the southwestern Gulf of Mexico.

6. Salas Pérez JJ, Ocaña Valencia Angel Norberto, Carlos González Gandara (2015) Temperatura superficial del mar y concentración de Clorofila-a en zonas arrecifales y desembocadura de sus ríos en el golfo de México occidental.

7. Salas Pérez JJ, Monreal DS, Monreal Gómez MA, Enzástiga MLA, Carme Llasat (2012) Seasonal Absolute Acoustic Intensity, Atmospheric Forcing and Currents in a Tropical Coral Reef System." Estuarine Coastal and Shelf Science 100: 102-112.

8. Salas Monreal D, Salas-de-León DA, Monreal-Gómez MA, RiverónEnzástiga MA (2009) Current rectification in a tropical coral reef system. Coral Reefs 28: 871-879.

9. Monreala DS, Hernandez MM, Salas Pereza JJ, David Alberto Salas, Monreal-Gomez MA, et al. (2018) Coral reef connectivity within the western Gulf of Mexico. J Mar Syst 179: 88-99. 